\title{
Human Alveolar Macrophages: Comparison of Phagocytic Ability, Glucose Utilization, and
} Ultrastructure in Smokers and Nonsmokers

\author{
James O. Harris, Edward W. Swenson, and Joseph E. Johnson III \\ From the Divisions of Pulmonary and Infectious Diseases, Department of \\ Medicine, College of Medicine, University of Florida, \\ Gainesville, Florida 32602
}

A в S T R A C T Phagocytic ability, glucose utilization, and ultrastructural morphology were studied in human alveolar macrophages in smokers and nonsmokers. The macrophages were obtained by bronchopulmonary lavage and the studies were carried out in vitro in the absence of smoke. Phagocytic ability was measured as the decrease in the number of viable Staphylococcus albus organisms incubated with the macrophages. Measurements of ${ }^{14} \mathrm{CO}_{2}$ formation from glucose- $\mathrm{U}_{-}{ }^{14} \mathrm{C}$ were made in a resting state. $90-95 \%$ of the cells obtained by lavage were large mononuclear macrophages of which approximately $90 \%$ remained viable at the end of the experiment. Smokers yielded many more macrophages per lavage (mean $46.4 \times 10^{8} \pm 7.4$ ) compared to the nonsmokers (mean $10.2 \times 10^{8} \pm 2.3$ ). The decline in viable organisms was the same in each group, indicating phagocytic competence of alveolar macrophages removed from smokers. However, the mean glucose utilization for the smokers was $4.3 \pm 0.2 \mathrm{~m} \mu$ moles $/ 10^{\circ}$ cells and $1.4 \pm 0.7 \mathrm{~m} \mu \mathrm{moles} / 10^{8}$ cells for the nonsmokers. This very significant difference $(P<0.0001)$ suggests that smokers' macrophages have a higher resting energy requirement than those of nonsmokers. Comparison of the ultrastructural morphology of the alveolar macrophages from each group reveals that the cells from smokers differ from those of nonsmokers in that they are slightly larger, and contain more golgi vesicles, endoplasmic reticulum, and residual bodies. The residual bodies in smokers' cells contain distinctive fiber-like inclusions.

\section{INTRODUCTION}

Alveolar macrophages have been shown to be of primary importance in maintaining sterility of the lower

Received for publication 9 April 1970 and in revised form 6 July 1970. respiratory tract $(1,2)$. Using radioactively labeled bacteria, Laurenzi, Guarneri, Endriga, and Carey demonstrated that while the number of viable organisms disappeared rapidly from the lung parenchyma, the amount of radioactivity disappeared at a much slower rate (3). These observations indicate that material phagocytized by macrophages remains in the lungs until the macrophages are removed either by the "mucociliary escalator" or by migration into regional lymph nodes. If infectious agents or toxic materials which are inhaled or aspirated are not removed or neutralized by alveolar macrophages, pathological changes may be produced; accordingly characterization of the role of alveolar macrophages in various pulmonary illnesses appears to be important.

In 1967, Green and Carolin studied the effect of cigarette smoke on the function of rabbit alveolar macrophages and noted depression of phagocytic function by cigarette smoke in vitro (4). Myrvik and Evans found that nitrogen dioxide, an oxidant gas, inhibited both phagocytosis and glucose metabolism of rabbit alveolar macrophages (5). Recently, Gee, Vasallo, Bell, and Basford reported an inhibitory effect of nitrogen dioxide and nitrate ion upon hydrogen peroxide metabolism of rabbit alveolar macrophages during phagocytosis (6). They suggest that this inhibitory effect may decrease the bactericidal capability of rabbit macrophages. Since cigarette smoke is the most common noxious agent inhaled by man in high concentration, it was decided to examine the phagocytic function, metabolism, and ultrastructure of human pulmonary alveolar macrophages, and in particular to compare macrophages in smokers and nonsmokers.

\section{METHODS}

Alveolar macrophages were obtained from 11 normal subjects. All subjects had a negative history for cardiorespiratory complaints, and a normal physical examination. Chest 
TABLE I

Subjects: Human Alveolar Macrophage Donors

\begin{tabular}{|c|c|c|c|c|c|c|c|c|c|}
\hline \multirow[b]{2}{*}{ Subject } & \multirow[b]{2}{*}{ Age } & \multirow[b]{2}{*}{ Sex } & \multirow[b]{2}{*}{$\mathrm{Ht}$. } & \multicolumn{2}{|c|}{ Spirometry } & \multicolumn{2}{|c|}{ Cigarette } & \multicolumn{2}{|c|}{ Respiratory symptoms } \\
\hline & & & & $\begin{array}{c}\text { Predicted } \\
\text { FVC/FEV } 1.0\end{array}$ & $\begin{array}{c}\text { Observed } \\
\text { FVC/FEV1.0 }\end{array}$ & Pack & Brand & Cough & Sputum \\
\hline & $y r$ & & $\mathrm{~cm}$ & & & $y r^{*}$ & & & $c c / d a y$ \\
\hline \multicolumn{10}{|c|}{ Nonsmokers } \\
\hline J. H. & 28 & M & 182 & $5.10 / 4.40$ & $5.30 / 4.00$ & $3 \ddagger$ & 0 & 0 & 0 \\
\hline E. S. & 43 & $\mathbf{M}$ & 188 & $4.80 / 3.80$ & $5.60 / 4.10$ & $15 \ddagger$ & 0 & 0 & 0 \\
\hline J.F. & 27 & $\mathrm{~F}$ & 167 & $3.30 / 2.80$ & $3.20 / 2.80$ & 0 & 0 & 0 & 0 \\
\hline P. J. & 20 & $F$ & 157 & $3.10 / 2.60$ & $3.10 / 2.60$ & 0 & 0 & 0 & 0 \\
\hline C. $\mathrm{N}$. & 24 & $\mathbf{M}$ & 178 & $4.95 / 4.20$ & $5.40 / 4.60$ & 0 & 0 & 0 & 0 \\
\hline \multicolumn{10}{|l|}{ Simokers } \\
\hline J. R. & 38 & $\mathbf{M}$ & 181 & $4.60 / 3.70$ & $5.30 / 3.90$ & 60 & Pall Mall & a.m. & 5 \\
\hline T. A. & 25 & $\mathbf{M}$ & 181 & $5.00 / 4.20$ & $5.50 / 4.30$ & 19 & Camel & a.m. & 15 \\
\hline F. S. & 28 & $\mathbf{M}$ & 166 & $4.30 / 3.40$ & $3.60 / 2.80$ & 30 & State $\S$ & a.m. & 30 \\
\hline J.F. & 27 & M & 168 & $4.40 / 3.50$ & $3.50 / 2.80$ & 6.5 & Lucky Strike & 0 & 0 \\
\hline W. Mc. & 42 & $\mathbf{M}$ & 174 & $4.30 / 3.60$ & $4.40 / 3.60$ & 48 & State $\S$ & a.m. & 10 \\
\hline L. N. & 30 & $\mathbf{M}$ & 163 & $4.10 / 3.30$ & $3.60 / 2.90$ & 15 & Camel & a.m. & 15 \\
\hline
\end{tabular}

* One pack year is equivalent to 20 cigarettes each day for 1 year.

$\ddagger$ Stopped smoking $8 \mathrm{yr}$ before this study.

$\S$ Nonfiltered regular sized cigarette made by inmates at the Florida State Prison.

$\mathrm{X}$-ray and spirometry were within normal limits. Five of the subjects were nonsmokers and six were cigarette smokers (Table I).

Bronchopulmonary lavage was used to obtain the macrophages (7). Using topical xylocaine anesthesia, the trachea was intubated with a size 19 (French) Metras ${ }^{1}$ bronchographic catheter. By inflating the latex cuff at the catheter tip a portion of the lower lobe was isolated and lavaged with four to five $50-\mathrm{ml}$ aliquots of normal saline. The lavage fluid returned was collected in $50-\mathrm{ml}$ sterile tubes and was centrifuged at $250 \mathrm{~g}$ for $10 \mathrm{~min}$. The cell buttons were resuspended in Hanks' solution and cell counts were done with a hemocytometer. Appropriate dilutions were made to give a cell count between 1.3 and $1.5 \times 10^{\circ}$ cells per ml.

A standard culture of Staphylococcus albus (coagulase negative) was used in all experiments, and a standard suspension was prepared by growing an inoculum in broth for $18 \mathrm{hr}$ at $37^{\circ} \mathrm{C}$. The broth suspension was centrifuged and washed twice with saline. A final saline suspension of the bacteria was diluted to give 0.4 absorbance at wave length $450 \mathrm{~m} \mu$ on a colorimeter/spectrophotometer, and pour plates were made to determine the original number of viable organisms for each experiment. This procedure reproducibly yielded a suspension of $3 \times 10^{8} \pm 1 \times 10^{8}$ organisms.

An in vitro method similar to that of Green and Carolin (4) was used to measure phagocytic activity of the macrophages. Flasks for phagocytic studies were prepared by adding $1.6 \mathrm{ml}$ suspension of macrophages $\left(1.3-1.5 \times 10^{\circ}\right.$ cells per $\mathrm{ml}$ ), $0.2 \mathrm{ml}$ autologous serum, and $0.2 \mathrm{ml} S$. albus suspension to $25-\mathrm{ml}$ flat bottomed plastic tissue culture flasks: This resulted in a total volume of $2.0 \mathrm{ml}$ which covered the growing surface of the flasks as a thin layer. The flasks were incubated in a metabolic shaker with the water bath maintained at $37^{\circ} \mathrm{C}$. $0.1 \mathrm{ml}$ was removed initially and at hourly intervals for $3 \mathrm{hr}$ to quantify the number

${ }^{1}$ Catalog No. 4250, Rüsch, Inc., New York. of viable organisms present. Two flasks were used in each experiment and duplicate pour plates from each flask were made at each interval. A control flask which contained 1.6 $\mathrm{ml}$ of Hanks' solution, $0.2 \mathrm{ml}$ of serum, and $0.2 \mathrm{ml}$ of $S$. albus suspension was incubated and sampled along with the experimental flasks each time.

At the end of the experiment, macrophage viability counts were made by the eosin $\mathrm{Y}$ dye-exclusion test of Hanks and Wallace (8). Smears were made from each flask, and Giemsa stains were done to determine the percentage of cells that had phagocytized bacteria.

Alveolar macrophage glucose utilization in a resting state was measured in four nonsmokers and three smokers. This was accomplished by incubating $2 \mathrm{ml}$ of the macrophage suspension $\left(1.3-1.5 \times 10^{8} \mathrm{cell} / \mathrm{ml}\right)$, and $3 \mathrm{ml}$ of Hanks' solution (5.5 mM glucose) which contained $2.21 \mu \mathrm{Ci}$ of uniformly labeled glucose $-{ }^{14} \mathrm{C}$ in a $25-\mathrm{ml}$ stoppered Erlenmeyer flask with a center well (9). Specific activity of the glucose $-{ }^{14} \mathrm{C}$ solution was $193,173 \mathrm{dpm} / \mu$ mole glucose. This was placed in a metabolic shaker at $37^{\circ} \mathrm{C}$ for $3 \mathrm{hr}$. After 3 hr $0.3 \mathrm{ml}$ Hyamine ( $p$-[diisobutylcresoxyethoxyethyl]-dimethylbenzylammonium hydroxide) was injected into the center well, and $0.5 \mathrm{ml}$ of $10 \mathrm{~N} \mathrm{HCl}$ was added to the flask to stop the reaction. The incubation was continued for 30 min to allow maximum trapping of carbon dioxide. Controls to measure spontaneous decarboxylation were included with each experiment. Each center well was placed directly into $10 \mathrm{ml}$ of scintillation solution: $7.2 \mathrm{~g}$ POP (2,5-diphenyloxazole) and $0.18 \mathrm{~g}$ POPOP ( $p$-bis[2-(5-phenyloxazolyl)]benzene) per liter of toluene. Radioactivity was measured using a liquid scintillation spectrometer. The results were expressed as radioactive counts per $10^{\circ}$ cells and ${ }^{11} \mathrm{CO}_{2}$ per m $\mu$ moles glucose per $10^{\circ}$ cells after correction for spontaneous decarboxylation.

For electron microscopic studies $10 \mathrm{cc}$ of lavage fluid was added to an equal amount of $2 \%$ gluteraldehyde and centri- 
fuged at $2000 \mathrm{~g}$ for $30 \mathrm{~min}$. The cell button obtained was cut and fixed in 2.5\% gluteraldehyde in phosphate buffer (ph 7.2) for $2 \mathrm{hr}$ at $4^{\circ} \mathrm{C}$. The specimen was postfixed in $2 \%$ osmic acid in phosphate buffer $(\mathrm{pH} 7.2)$, dehydrated rapidly with increasing concentrations of acetone, and embedded in Epon 812. Sections were cut with a diamond knife, stained with uranyl acetate and lead citrate, and examined for this study.

The data from the two groups of subjects was analyzed for statistically significant differences by the $t$ test for unpaired experiments (10).

\section{RESULTS}

Subjects. The age, sex, height, forced vital capacity (FVC), forced expiratory volume in 1 sec $\left(F^{2} V_{1.0}\right)$, and smoking history for all subjects are shown in Table I. The average age of the nonsmoking group was $28.4 \mathrm{yr}$ which was slightly younger than the average of $31.3 \mathrm{yr}$ for the smoking group. The sex ratio differed in the two groups but since the data for females and males within the nonsmoking group were similar the findings were presumably not affected. Although the observed vital capacity of several of the smoking group (F. S., J. F., and L. N.) was less than the predicted values, they fell within the normal range of $\pm 20 \%$ of predicted.

One subject in the nonsmoker group had been a regular smoker of one package of cigarettes per day for $3 \mathrm{yr}$ but had stopped $8 \mathrm{yr}$ before this study. Subject E. S. had smoked regularly for $15 \mathrm{yr}$ in the past and still occasionally smoked cigarettes but total consumption had not exceeded one pack per month in several years. The other three subjects abstained completely. In the smokers' group, cigarette consumption ranged from "light" by J. F. with a 6.5 pack year ${ }^{2}$ history to "heavy" by J. R. who smoked three packages a day. The average exposure to cigarettes in this group was 29.7 pack years. Three of the subjects primarily smoked commercial unfiltered cigarettes, but also at times smoked noncommercial cigarettes; therefore, the effect of filters or different brands could not be studied.

The other two subjects smoked primarily the same noncommercial cigarettes which were manufactured at the prison. These cigarettes are made from locally grown commercial-type Virginia bright leaf tobacco, typical of tobacco from this region which is purchased by national cigarette manufacturers. Analysis of this tobacco revealed the content of "tars" and nicotine to be similar to that of commercial cigarettes.

No one in the nonsmoking group complained of respiratory symptoms. In contrast all but one (J. F) of the smokers had an early morning cough productive of small amounts of nonpurulent sputum.

\footnotetext{
${ }^{2}$ One pack year is equivalent to 20 cigarettes each day for $1 \mathrm{yr}$.
}

All of the smokers were residents of the Florida State Prison, as was one of the controls. The prison is located in rural North Florida where overt air pollution is minimal. The remaining subjects were residents of Gainesville (population 60,000), 40 miles distant, where air pollution is also relatively low.

Bronchopulmonary lavage was performed as an outpatient procedure and was well tolerated by all subjects. Except for slight transient decrease in vital capacity and nitrogen washout no changes in pulmonary function were observed in those subjects who had serial pulmonary function studies performed following the lavage. This study demonstrates that bronchopulmonary lavage can be carried out with ease and safety in healthy subjects for the procurement of human alveolar macrophages.

Details concerning the material obtained by pulmonary lavage are indicated in Table II. In the smokers' group an average of $54 \%$ of the lavaged fluid was returned as compared to $64 \%$ from the nonsmokers. This difference is not statistically significant. Striking differences were observed however in the number of cells lavaged from the lungs of smokers as compared to nonsmokers. The nonsmokers averaged $10.2 \times 10^{6}$ cells per lavage while the smokers averaged $46.4 \times 10^{\circ}$, with no overlap between the two groups. In both groups macrophages obtained by lavage were large mononuclear cells which were easily distinguished from leukocytes. $90-95 \%$ of the total cells had the morphological appearance of macrophages and the remaining 5-10\% were typical of leukocytes. Lavage fluids from the smoking and nonsmoking groups were easily distinguishable by color. All smokers' lavage fluids were brown in contrast to the white, slightly cloudy lavage fluids of the nonsmokers. Cell buttons obtained by centrifugation were dark brown in the smokers and greyish-green in that of the nonsmoking group.

There were no significant differences in the percentages of viable cells in each group as determined by dye-exclusion at the end of the 3-hr incubation periods (Table II). Giemsa stains made from each experimental flask at the end of each experiment showed an average of $23 \%$ of bacteria-containing cells in the nonsmoker group and $18.5 \%$ in the smokers. It would thus appear that relatively small numbers of macrophages from both groups were able to phagocytize bacteria.

Macrophage phagocytic ability. The system used to measure phagocytic ability of the macrophages gave reproducible results which allowed comparison between relatively small numbers of subjects. The variables inherent in such a biological system were minimized by comparing the differences in per cent of viable bacteria between each experimental flask and its own control. Table III presents the data for a typical experiment, 
TABLE II

Bronchopulmonary Lavage

\begin{tabular}{|c|c|c|c|c|c|}
\hline \multirow[b]{2}{*}{ Subject } & \multicolumn{2}{|c|}{ Lavage } & \multicolumn{3}{|c|}{ Cells } \\
\hline & $\mathrm{ml}$ in & $\mathrm{ml}$ out & Color & No. obtained & Viability \\
\hline \multicolumn{6}{|c|}{ Nonsmokers } \\
\hline J. H. & 200 & 100 & White & $8.0 \times 10^{6}$ & 88 \\
\hline E. S. & 225 & 100 & White & $12.6 \times 10^{6}$ & 83 \\
\hline J. F. & 225 & 170 & White & $7.7 \times 10^{6}$ & 88 \\
\hline P. J. & 240 & 200 & White & $9.7 \times 10^{6}$ & 98 \\
\hline C. $\mathrm{N}$. & 250 & 175 & White & $13.3 \times 10^{6}$ & 91 \\
\hline \multicolumn{6}{|l|}{ Mean } \\
\hline$\pm \mathbf{S E}$ & $228 \pm 8$ & $149 \pm 18$ & White & $10.2 \times 10^{6} \pm 2.3$ & $90 \pm 2$ \\
\hline \multicolumn{6}{|l|}{ Smokers } \\
\hline J. R. & 225 & 100 & Brown & $51.8 \times 10^{6}$ & 83 \\
\hline T. A. & 240 & 160 & Brown & $53.2 \times 10^{6}$ & 94 \\
\hline F. S. & 240 & 100 & Brown & $35.4 \times 10^{6}$ & 88 \\
\hline J. F. & 220 & 100 & Brown & $55.0 \times 10^{6}$ & 91 \\
\hline W. Mc. & 220 & 130 & Brown & $39.0 \times 10^{6}$ & 90 \\
\hline L. N. & 205 & 140 & Brown & $44.0 \times 10^{6}$ & 91 \\
\hline \multicolumn{6}{|l|}{ Mean } \\
\hline$\pm \mathrm{SE}$ & $225 \pm 5$ & $122 \pm 10$ & Brown & $46.4 \times 10^{6} \pm 7.4$ & $90 \pm 1$ \\
\hline
\end{tabular}

showing the number of viable organisms initially and at hourly intervals for $3 \mathrm{hr}$ in the control and experimental flasks, the per cent of the initial counts remaining at each interval and the differences between control and experimental flasks. Table IV gives the data from each experiment expressed as per cent of initial bacterial count. Fig. 1 graphically depicts the decrease in bacteria and compares the ability of macrophages from smokers and nonsmokers to phagocytize and kill $S$. albus. Mean values of the two groups and the standard errors of the mean are noted for each point. The maximum drop in viable bacteria occurred during the 1st hour and was identical in the two groups. The magnitude and rate of decline was approximately the same for both groups at 2 and $3 \mathrm{hr}$.. The difference between each group and its own control was statistically significant at each time interval $(P<0.02)$. Reproducibility of results in this system compares favorably with that of Green and Carolin (4) and that of Cohn and Morse (11). Using a similar monolayer culture-flask system, Green and Carolin (4) noted that phagocytosis by alveolar macrophages removed bacteria at a similar rate over a 2 -hr period. Although relatively small, the quantitative differences were significant and the results highly reproducible

It is likely that more efficient phagocytosis could be achieved by altering the ratio of bacteria per cell and by the use of a tumbling system. It would also be desirable to utilize additional test organisms. Characteristically the bacteria continued to multiply in control flasks, which contained $10 \%$ serum without macrophages, giving average counts greater than the initial bacterial count at each interval except at $3 \mathrm{hr}$ in the smoking group. These data indicate that in vitro the

TABLE III

Human Alveolar Macrophages: Phagocytosis and Inactivation of Staphylococcus Albus

\begin{tabular}{|c|c|c|c|c|c|c|c|}
\hline \multirow[b]{2}{*}{ Time } & \multicolumn{3}{|c|}{ Number viable bacteria } & \multicolumn{3}{|c|}{$\%$ Initial count } & \multirow{2}{*}{$\frac{\substack{\% \text { Control } \\
\text { minus \% } \\
\text { flask* }}}{}$} \\
\hline & Control & $\begin{array}{l}\text { Flask } \\
\text { No. } 1\end{array}$ & $\begin{array}{l}\text { Flask } \\
\text { No. } 2\end{array}$ & Control & $\begin{array}{l}\text { Flask } \\
\text { No. } 1\end{array}$ & $\begin{array}{l}\text { Flask } \\
\text { No. } 2\end{array}$ & \\
\hline Initial & $3.12 \times 10^{5}$ & $3.00 \times 10^{5}$ & $3.10 \times 10^{5}$ & 100 & 100 & 100 & \\
\hline $1 \mathrm{hr}$ & $2.99 \times 10^{5}$ & $1.94 \times 10^{5}$ & $1.80 \times 10^{5}$ & 96 & 65 & 58 & 34 \\
\hline $2 \mathrm{hr}$ & $4.40 \times 10^{5}$ & $1.33 \times 10^{5}$ & $1.77 \times 10^{5}$ & 142 & 44 & 57 & 91 \\
\hline $3 \mathrm{hr}$ & $3.40 \times 10^{5}$ & $1.19 \times 10^{5}$ & $1.51 \times 10^{5}$ & 110 & 40 & 49 & 65 \\
\hline
\end{tabular}

* Average of flasks No. 1 and No. 2. 
TABLE IV

Human Alveolar Macrophages: Viable Bacteria Remaining at Hourly Intervals Expressed as Per Cent of Initial Count

\begin{tabular}{|c|c|c|c|c|c|c|}
\hline \multirow[b]{2}{*}{ Subject } & \multicolumn{3}{|c|}{ Control } & \multicolumn{3}{|c|}{ Experimental* } \\
\hline & $1 \mathrm{hr}$ & $2 \mathrm{hr}$ & $3 \mathrm{hr}$ & $1 \mathrm{hr}$ & $2 \mathrm{hr}$ & $3 \mathrm{hr}$ \\
\hline \multicolumn{7}{|c|}{ Nonsmoker } \\
\hline J. H. & 146 & 123 & 106 & 77 & 67 & 63 \\
\hline E. S. & 96 & 142 & 110 & 62 & 51 & 45 \\
\hline J. F. & 94 & 99 & 123 & 61 & 38 & 29 \\
\hline P. J. & 96 & 118 & 88 & 66 & 55 & 52 \\
\hline C. N. & 102 & 105 & 143 & 24 & 17 & 4 \\
\hline $\begin{array}{l}\text { Mean } \\
\pm \mathrm{SE}\end{array}$ & $107 \pm 9$ & $117 \pm 7$ & $114 \pm 8$ & $58 \pm 8$ & $46 \pm 8$ & $39 \pm 9$ \\
\hline \multicolumn{7}{|l|}{ Smokers } \\
\hline J. R. & 100 & 98 & 106 & 76 & 72 & 60 \\
\hline T. A. & 146 & 133 & 36 & 58 & 33 & 7 \\
\hline F. S. & 104 & 144 & 63 & 84 & 94 & 91 \\
\hline J. F. & 81 & 86 & 106 & 62 & 23 & 12 \\
\hline W. Mc & 97 & 92 & 129 & 43 & 33 & 28 \\
\hline L. N. & 114 & 117 & 91 & 27 & 15 & 5 \\
\hline $\begin{array}{l}\text { Mean } \\
\pm \mathrm{SE}\end{array}$ & $107 \pm 9$ & $112 \pm 9$ & $89 \pm 13$ & $58 \pm 7$ & $45 \pm 12$ & $34 \pm 13$ \\
\hline
\end{tabular}

* Represents average of experimental flask No. 1 and No. 2.

alveolar macrophages from cigarette smokers have the same phagocytic and bactericidal capacity as the macrophages from nonsmokers.

Glucose metabolism. Resting glucose utilization by alveolar macrophages, as measured by ${ }^{14} \mathrm{CO}_{2}$ formation, from smokers and nonsmokers was found to be quite different (Table V). The nonsmoking group had an average glucose utilization of $1.4 \pm 0.7 \mathrm{~m} \mu$ moles per $10^{\circ}$ cells and the smokers' utilization averaged $4.3 \pm 0.2$ m $\mu$ moles per $10^{\circ}$ cells. This difference was highly significant $(P<0.001)$ and suggests that alveolar macrophages from smokers have a higher glucose requirement than macrophages from nonsmokers.

Ultrastructure. The salient ultrastructural features of normal human alveolar macrophages are illustrated in Fig. 2. These cells have a cytoplasm of uniform density and contain a single nucleus. There are numerous cytoplasmic "foot processes" projecting from the cell surface. Measurement of 57 randomly selected cells revealed their diameters to vary from 10 to $47 \mu$, with the average being $23.3 \mu$. Human alveolar macrophages contain the usual intracellular organelles as well as many vacuoles and inclusion bodies. The golgi system is well developed and mitochondria are plentiful. The endoplasmic reticulum is sparse and predominantly of the rough type. Ribosomes are seen within the cells singly and in small clusters, as well as in association with the endoplasmic reticulum. Filaments are found scattered throughout the cytoplasm and also in bundles. The many dense bodies seen within the cell mostly represent secondary lysosomes in various stages of digestion. Vacuolar structures of varying sizes which are a consequence of pinocytotic or autophagic functions are seen within the macrophages.

TABLE V

Human Alveolar Macrophages: Resting Glucose Utilization Measured by Glucose- $U-14 C$

\begin{tabular}{cll}
\hline & \multicolumn{2}{c}{${ }^{14} \mathrm{CO}_{2}$} \\
\cline { 2 - 3 } Subject & $\mathrm{cpm} / 10^{6}$ cells & $\mathrm{m} \mu$ mole/106 cells \\
\hline Nonsmokers & & 1.3 \\
J. H. & 2499.5 & 0.9 \\
E. S. & 1651.3 & 0.7 \\
P. J. & 1363.9 & 2.6 \\
C. N. & 5010.6 & \\
Mean & & $1.4 \pm 0.7$ \\
\pm SE & $2606.3 \pm 828$ & \\
Smokers & & 4.3 \\
J. F. & 8296.2 & 4.0 \\
W. Mc & 7744.8 & 4.5 \\
L. N. & 8709.8 & \\
Mean & & $4.3 \pm 0.2$ \\
土SE & $8250.3 \pm 280$ &
\end{tabular}




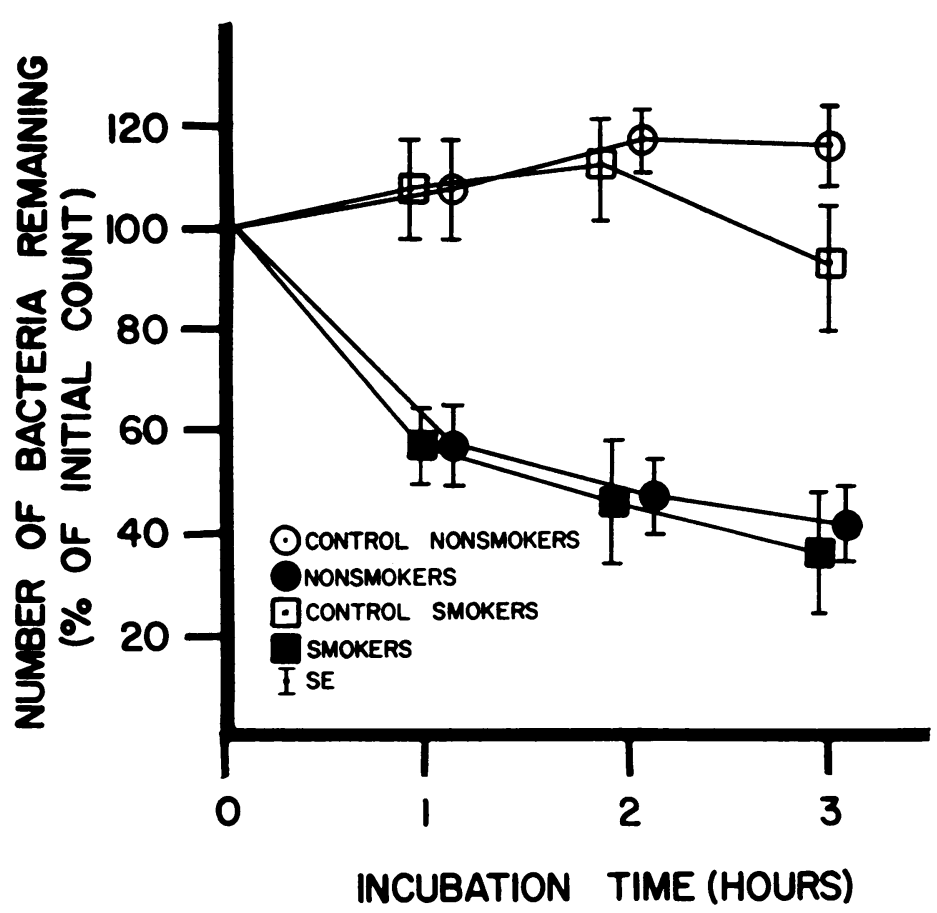

FIGURE 1 Decrease in viable bacteria. $S$. albus organisms were incubated with alveolar macrophages from smokers and nonsmokers and quantitative cultures were made at hourly intervals. Controls contained no macrophages.

Fig. 3 demonstrates the differences between smokers' and nonsmokers' macrophages. The most striking differences are the larger and more numerous lysosomal bodies in the smokers' cells. There is a modest but definite increase in endoplasmic reticulum and ribosomes in the smokers' cells. Although the macrophages from the smokers do not appear to have a more extensive golgi apparatus, there do appear to be more golgi vesicles present. Measurement of 69 randomly selected cells revealed variation in diameter between 12 and $53 \mu$, but the average cell was $26.4 \mu$ in diameter.

The large residual bodies within the smoker's cells contained material of various densities but the fiberlike structures (Fig. 4) are of particular interest. These structures were abundant in the smokers and were not seen in any of the nonsmokers. The nature of these structures cannot be determined from their ultrastructural appearance but their presence seems to be clearly related to cigarette smoking.

\section{DISCUSSION}

The complex chemical composition of tobacco smoke has recently been reviewed by Stedman (12). Many of the acids, aldehydes, hydrocarbons, and phenols in the particulate or discontinuous phase have been shown to be lung irritants and possibly carcinogens. The vapors of formaldehyde, acetaldehyde, acrolein, ammonia, and hydrogen cyanide may cause ciliostasis and along with the other gases are also lung irritants (13). The marked proliferation of pulmonary macrophages in the smokers in this study indicates that even in the asymptomatic smoker there is a significant stimulation of the mononuclear defense system without an apparent parallel increase in the number of polymorphonuclear leukocytes. One may speculate that alveolar macrophages play an important role in inactivating toxic components of cigarette smoke. Without this proliferative stimulus, the irritating and carcinogenic components of tobacco smoke would presumably reach relatively higher concentrations within the lung and contribute even more to the pathogenesis of chronic respiratory illness. A protective role for these cells is supported by the ultrastructural morphology of alveolar macrophages from smokers which shows them to contain large amounts of phagocytized material which is not present in macrophages from nonsmokers.

Paradoxically, one could speculate that the local accumulation of macrophages in the lung as a defensive response may also contribute to the pathogenesis of chronic pulmonary disease by the release of lysosomal enzymes which may in turn lead to tissue damage. Such a mechanism has been postulated in the production of 


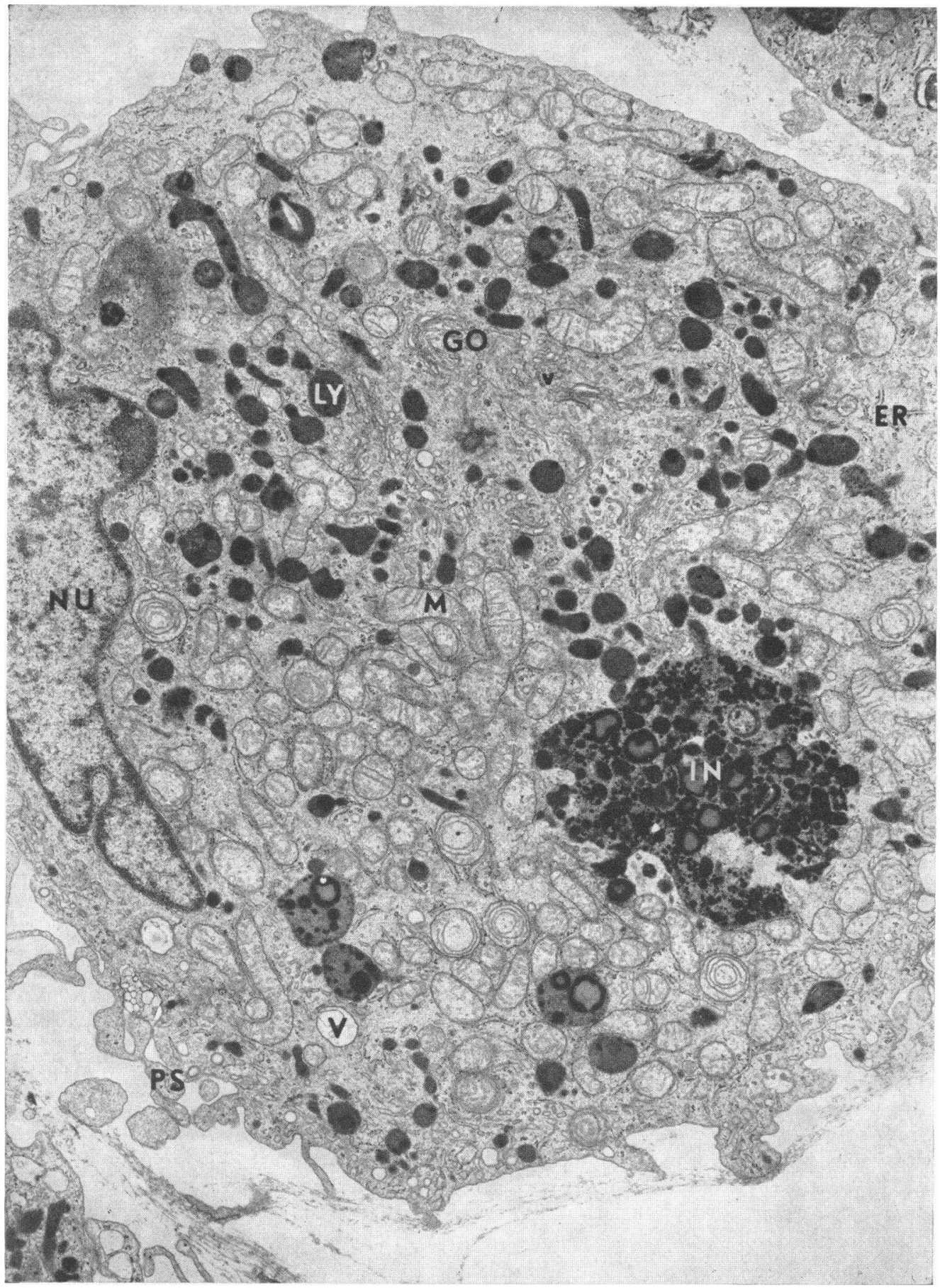

FIgURE 2 Human alveolar macrophage, nonsmokers. This large cell with a single nucleus (NU) and pseudopod-like structures (PS) at the cell surface contains numerous mitochondria (M), a well developed golgi apparatus (GO), sparse endoplasmic reticulum (ER), and various vacuoles (V). The large number of lysosomes (LY) indicates active phagocytosis with the large inclusion (IN) being formed by fusion of many of the smaller lysosomes. $\times 10,000$. 


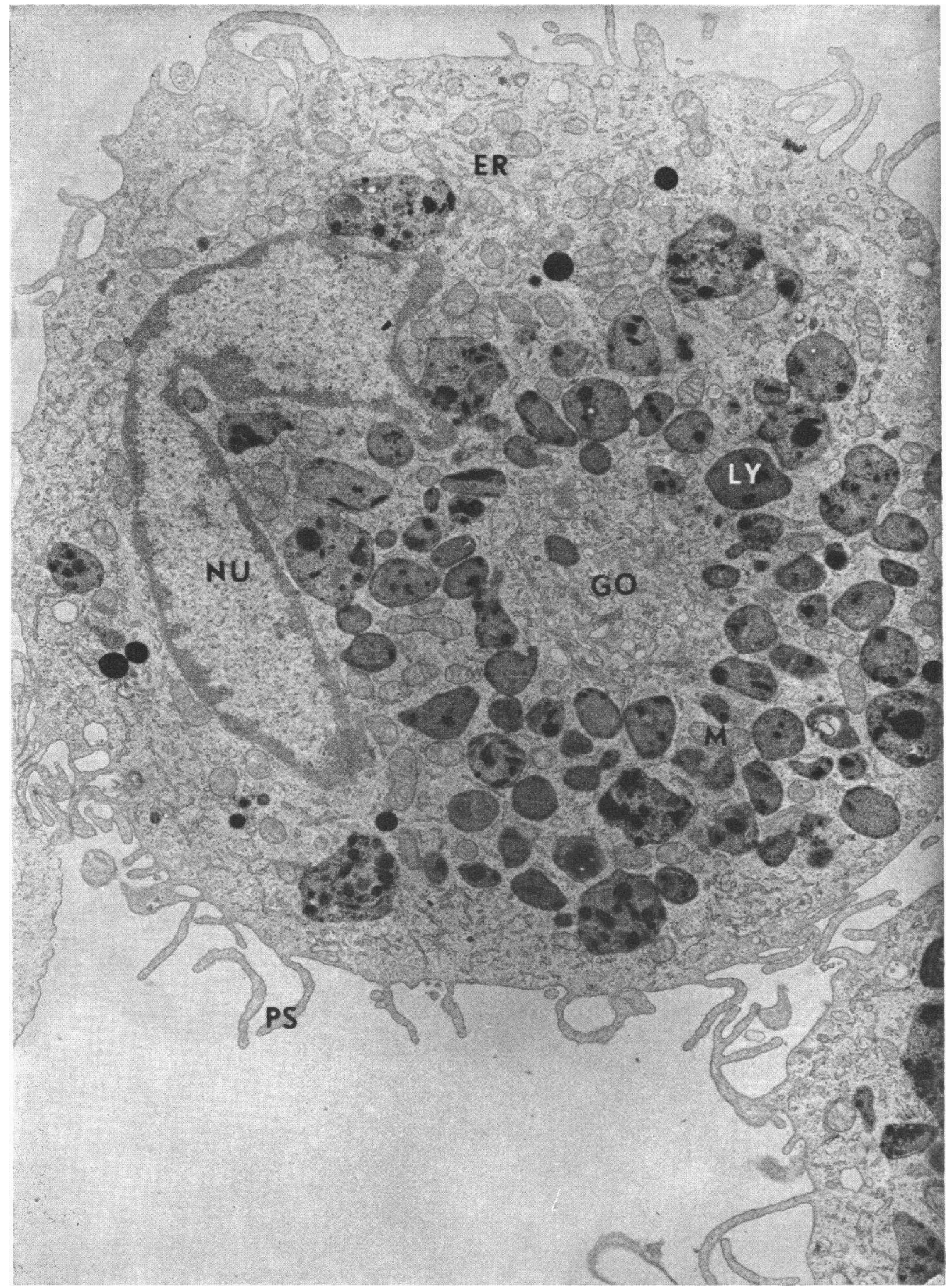

F!GURE 3 Human alveolar macrophage, smoker. This cell has an eccentric nucleus (NU) and a large central golgi zone (GO). Mitochondria (M) and endoplasmic reticulum (ER) are scattered throughout the cytoplasm of the cell. The many large lysosomal bodies (LY) is the most prominent difference between this cell and Fig. $1 . \times 10,000$. 


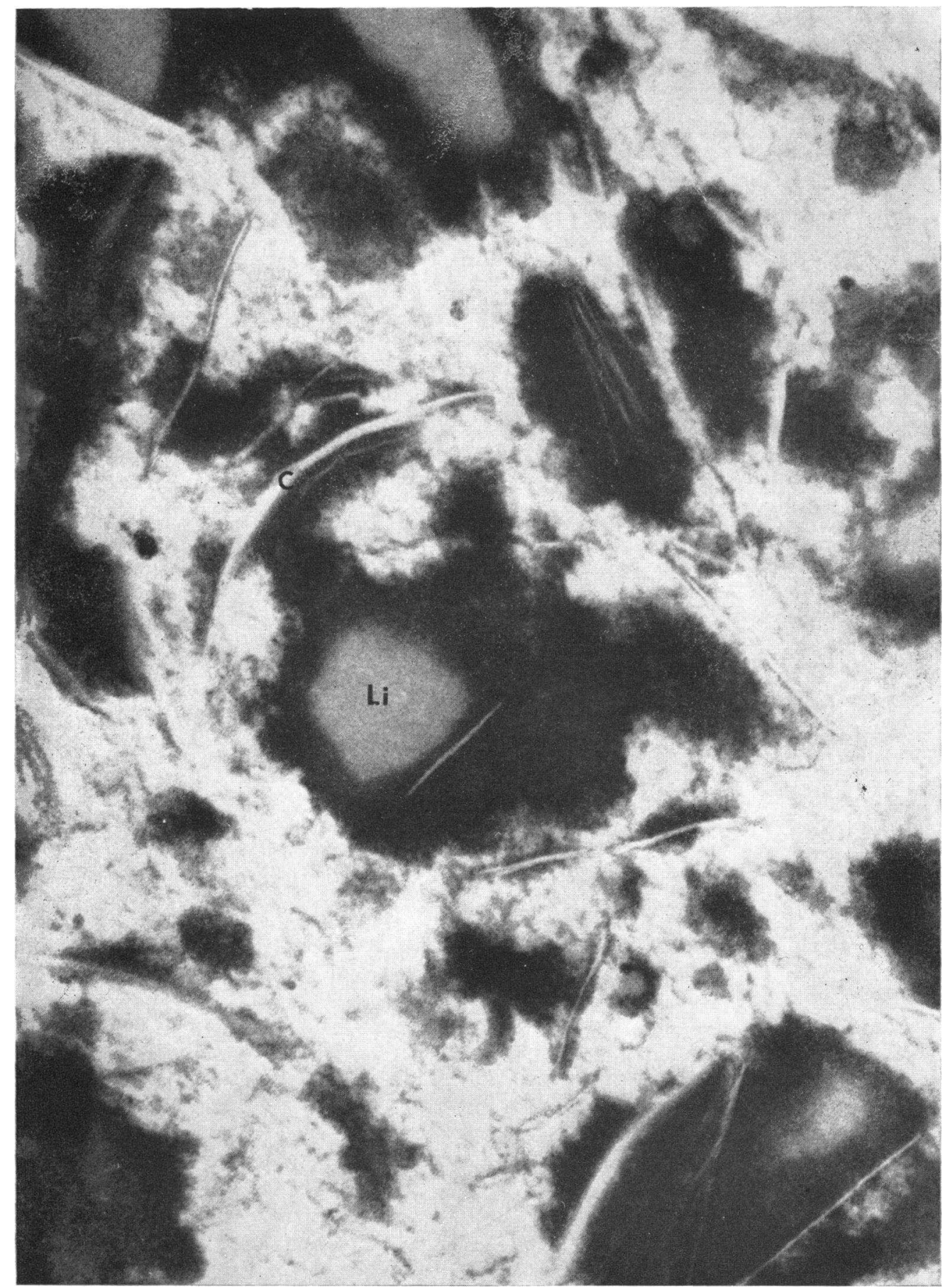

FIGURE 4 Human alveolar macrophage, smoker. This high magnification of a lysosome shows lipid (LI) material undergoing digestion and numerous fiber-like structures (C). The difference in appearance among these structures may indicate multiple origin. $\times 100,000$. 
pulmonary disease in patients with $\alpha_{1}$-antitrypsin deficiency (14). Similarly phagocytes have been incriminated in the production of inflammatory synovial reactions in patients with arthritic diseases (15). The large number of lysosomes noted in human alveolar macrophages suggest that they contain large quantities of hydrolytic enzymes similar to rabbit alveolar macrophages (16).

The brown color of both the supernate and cellular sediment of the smokers' lavage fluids is consonant with the brown pigments which constitute as much as $4 \%$ of the weight of tobacco smoke condensates. These pigments resemble the brown acidic polymeric substances of smoke which have been reported to act as cocarcinogens (12). The degree of discoloration of the lavage fluid suggests that these pigments are present in considerable concentration in the alveoli.

Cigarette smoke may have toxic effects on cell function (ciliary movement) and enzyme systems, but the high and equal percentage of viable macrophages obtained from both groups in this study suggests that cigarette smoke may not cause a significant degree of cell death in vivo.

The system selected in our studies for measurement of phagocytic function was similar to that of Green and Carolin who found that the gaseous phase of cigarette smoke was a phagocytic inhibitor of normal rabbit alveolar macrophages (4). They concluded that the phagocytic inhibitor was both water soluble and labile. It is quite possible in our studies that this inhibitor was removed from the lavage fluid during centrifugation and resuspension in Hanks' solution. We suggest that our study neither contradicts nor supports these animal experiments but rather indicates that in vitro in the absence of smoke, human alveolar macrophages from smokers are capable of phagocytizing and inactivating nonvirulent bacteria with the same facility as macrophages from nonsmokers. Cigarette smoke in vivo may inhibit the ability of alveolar macrophages to phagocytize virulent organisms and, combined with a concomitant depression of ciliary function, may result in a net decrease in resistance to infection. However, it is of interest that habitual smoking apparently does not permanently damage the phagocytic ability of these important cells. Additional studies on phagocytosis of pathogenic organisms are needed.

It was somewhat surpring that the smokers' macrophages actually had a much higher glucose utilization than did the nonsmokers since hydrogen cyanide is a known inhibitor of respiratory enzyme systems (13) and nitrogen dioxide has been shown to inhibit glucose utilization in a similar macrophage system (5). Again the inhibitor may have been removed in processing the cells, but our findings indicate a true metabolic difference which is probably operative in vivo as well. Although the mass of cells in the smokers' group was greater than nonsmokers in that the individual cells are slightly larger and glucose utilization was expressed in relationship to the number of cells rather than mass, we do not believe that greater mass alone accounted for the differences observed. While glucose utilization would be more meaningfully expressed on the basis of protein rather than on a per cell basis, a rough estimate of cell volume can be made from the measurement of cell diameter (a mean of $23.3 \mu$ for nonsmokers and $26.4 \mu$ for smokers). The larger cell volume of smokers' macrophages does not appear to be great enough to account for the threefold increase noted in glucose utilization. Assuming, however, that the increase in cell size of the smokers' macrophages could alone account for their greater glucose utilization, the magnitude of the difference would indicate a significant stimulatory effect upon these cells, presumably also reflected in the ultrastructural differences observed. We assume that the macrophages were in a resting state, but it is quite possible that the smokers' macrophages remained stimulated by the substances both foreign and autologous which were carried into the final cell suspension. It is known that in rabbit macrophages oxidation of glucose-1 $1{ }^{14} \mathrm{C}$ increases during phagocytosis (5, 17), and, if the cells continued to phagocytize during the incubation period, the glucose utilization would be greater in smokers' cells. Finally the ultrastructural findings suggest that the resting metabolic rate may be increased in macrophages from smokers because of the increased digestive load placed upon these cells. Obviously this study does not indicate the specific mechanisms responsible for the greater glucose utilization observed in smokers. A combination of factors may well be operative at the same time with stimulation having the greater expression. More detailed studies of glucose metabolism in human alveolar macrophages from smokers are needed to determine what metabolic pathways are involved and whether they differ from those of nonsmokers.

Note added in proof. After submission of this manuscript for publication, morphologic studies with ultrastructural findings similar to ours appeared (Pratt, S. A., T. N. Finley, M. H. Smith, and A. J. Ladman. 1969. Anat. Rec. 163: 497.).

\section{ACKNOWLEDGMENTS}

This study was supported by U. S. Public Health Service Grant A 110341, the U. S. Army Medical Research and Development Command, and the John A. Hartford Foundation, Inc. New York.

\section{REFERENCES}

1. Laurenzi, G. A., K. T. Potter, and E. H. Kass. 1961. Bacteriologic flora of the lower respiratory tract. N. Engl. J. Med. 265: 1273.

2. Kass, E. H., G. M. Green, and E. Goldstein. 1966. Mechanisms of antibacterial action in the respiratory system. Bacteriol. Rev. 30: 488. 
3. Laurenzi, G. A., J. J. Guarneri, R. B. Endriga, and J. P. Carey. 1963. Clearance of bacteria by the lower respiratory tract. Science (Washington). 142: 1572.

4. Green, G. M., and D. Carolin. 1967. The depressant effect of cigarette smoke on the in vitro antibacterial activity of alveolar macrophages. $N$. Engl. J. Med. 276: 421.

5. Myrvik, G. N., and D. G. Evans. 1967. Metabolic and immunologic activities of alveolar macrophages. Arch. Environ. Health. 14: 92.

6. Gee, J. B. L., C. L. Vassallo, P. Bell, and R. E. Basford. 1969. The effects of nitrogen dioxide and nitrate ion on hydrogen peroxide metabolism in alveolar macrophages during phagocytosis. J. Clin. Invest. 48: 272.

7. Finley, T. N., E. W. Swenson, W. S. Curran, G. L. Huber, and A. J. Ladman. 1967. Bronchopulmonary lavage in normal subjects and patients with obstructive lung disease. Ann. Intern. Med. 66: 651.

8. Hanks, J. H., and J. H. Wallace. 1958. Determination of cell viability. Proc. Soc. Exp. Biol. Med. 98: 188.

9. Cuppy, D., and L. Crevasse. 1961. An assembly for C-14- $\mathrm{O}_{2}$ collection in metabolic studies for liquid scintillation counting. Anal. Biochem. 5: 462.

10. Batson, H. C. 1956. An Introduction to Statistics in the
Medical Sciences. Burgess Publishing Company, Minneapolis. 1st edition.

11. Cohn, Z. A., and S. I. Morse. 1959. Interactions between rabbit polymorphonuclear leukocytes and staphylococci. J. Exp. Med. 110: 419.

12. Stedman, R. L. 1968. The chemical composition of tobacco and tobacco smoke. Chem. Rev. 68: 153.

13. United States Surgeon General's Advisory Committee on Smoking and Health. 1964. Smoking and health: report of the advisory committee to the surgeon general of the public health service. U. S. Public Health Serv. $P u b l$. No. 1103. 49: 65 .

14. Kueppers, F., and A. B. Bearn. 1966. A possible experimental approach to the association of hereditary alpha,-antitrypsin deficiency and pulmonary emphysema. Proc. Soc. Exp. Biol. Med. 121: 1207.

15. Weissman, G. 1967. The role of lysosomes in inflammation and disease. Ann. Rev. Med. 18: 97.

16. Leake, E. S., D. Gonzalez-Qjeda, and Q. N. Myrvik. 1964. Enzymatic difference between normal alveolar macrophages and oil induced peritoneal macrophages obtained from rabbits. Exp. Cell. Res. 33: 553.

17. Oren, R., A. E. Rarnham, K. Saito, E. Milofsky, and M. L. Karnovsky. 1963. Metabolic patterns in three types of phagocytic cells. J. Cell. Biol. 17: 487. 